\title{
Madrid versus Barcelona: Two Visions for the Modern City and Block (1929-36)
}

\author{
By Jean-Francois Lejeune
}

Figure 1. Le Corbusier and GATCPAC. Plan Macià, Barcelona, 1933. () Collegi d'Arquitectes de Catalunya, Barcelona

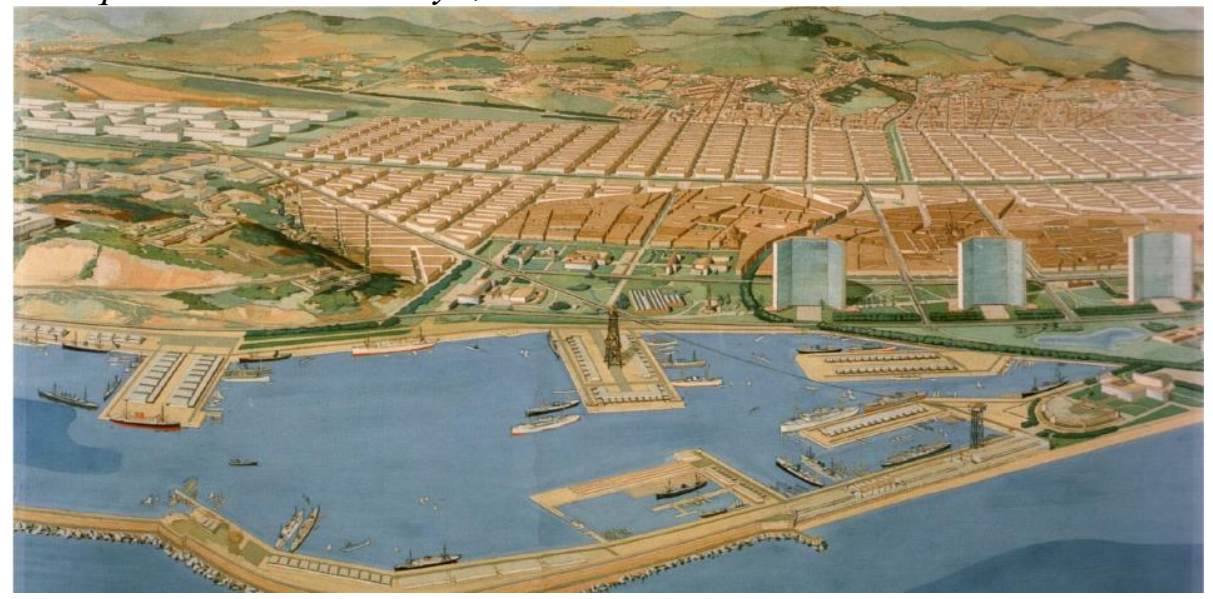

This essay proposes a comparative analysis between two parallel moments in the advancement of modern urbanism and urban housing in Spain before the Civil War: the most discussed in the historiography, the Plan Macià for Barcelona by José Luis Sert and the GATCPAC, in collaboration of Le Corbusier (1931-1938) (Figure 1); the Anteproyecto del trazado viario $y$ urbanización de Madrid by architect Secundino Zuazo Ugalde, with the initial collaboration of German planner Hermann Jansen (1929; 1930-1936). Unique in this situation is the fact that those Spanish architects built, at the same time than the master plan for their respective city, an experimental housing blockthe Casa Bloc (1933-1936) in Barcelona and the Casa de Las Flores in Madrid (1929-32)—whose urban and architectural characteristics concretized their conception of the modern city. The paper argues that, even though their respective visions of the city and blocks strongly differed in urban form and architectural language, they both embodied a particular Southern approach to the modern city and urban life, which contrasted with contemporary examples in Northern Europe. The master plans were not implemented, but the buildings, damaged or mutilated after 1936, have been renovated or reconstructed. They remain as two exceptional references in the short history of modernism in preCivil War Spain, as well as continuous sources of inspiration for contemporary housing in Spain.

Keywords: José Luis Sert, Modern housing, Modernism in Spain, Secundino Zuazo

${ }^{*}$ Professor, University of Miami, USA. 


\section{Barcelona: The Plan Maciá \& the Casa Bloc}

It is at the invitation of Madrid architect and CIAM member Fernando García Mercadal that Le Corbusier came to lecture in the capital. On May 15, 1928, at a stopover of the train in Barcelona, Le Corbusier was literally "intercepted" at the station:

In Madrid I received a telegram signed by José Luis Sert (whom I did not know at the time) who said he would meet at 10 o'clock in the evening in Barcelona station, an intermediate stop for the Madrid-Port-Bau express, and rush me off without delay to give a talk somewhere in the city. At Barcelona station I was received by five or six youths, all short but full of fire and energy."

Le Corbusier lectured on his way back in Barcelona. This was a moment of frustration and crisis in his career after the failure at the competition for the Palais des Nations in Geneva. At the same time his discourse about the "new architecture" was shifting away from the analogy of the machine toward an architecture where classical proportions, vernacular references, and Greekbased harmony could be harnessed to redefine modernity. ${ }^{2}$ After listening to Le Corbusier, Sert and his colleagues realized that there was therefore neither contradiction nor opposition between modernity and tradition, and it was possible to be truly modern without losing their Spanish roots. Hence, they set up to demonstrate that they were the heirs of an "autochthonous culture whose roots revealed the same preoccupations as those concerning Europe in the years immediately before," and that gave them the right to be now, albeit belatedly, at the forefront of the modernist movement. ${ }^{3}$ In working together on the Mediterranean and its vernacular as the primary sources of modern architecture, Le Corbusier, Sert, and others around Europe attempted to substantiate the myth of the origins beyond the machine and other technological analogies. ${ }^{4}$ In the late 1920s, Sert and his classmate Germán Rodriguez-Arias embarked on a series of journeys to discover the vernacular architecture of Spain's Southern towns and villages. ${ }^{5}$ Ibiza was the next step and there they joined a small crowd of intellectuals who saw in the "primitive"

\footnotetext{
${ }^{1}$ Le Corbusier, quoted by Josep Rovira, "The Mediterranean is his Cradle," J.LL. Sert and Mediterranean Culture, Barcelona: Colegio de Arquitectos de Cataluña, 1995, p. 49. Also see Juan José Lahuerta, Le Corbusier e la Spagna, Milano: Electa, 2006.

${ }^{2}$ See Le Corbusier, Une maison, un palais - A la recherche d'une unité architecturale, Paris: G. Crès, 1929.

${ }^{3}$ Josep Rovira, "The Mediterranean is His Cradle," pp. 63-64.

${ }^{4}$ See Jean-François Lejeune \& Michelangelo Sabatino (eds.), Modern Architecture and the Mediterrean: Vernacular Dialogues and Contested Identities, London: Routledge, 2010.

${ }^{5}$ See Josep Rovira, "Ibiza y la mirada de la vanguardia," in Urbanización en Punta Martinet, Ibiza, 1966-71, Almería: Colegio de Arquitectos, 1996, pp. 33-54; Josep Rovira, José Luis Sert, op. cit.; and Vicente Valero, Viajeros contemporaneous: Ibiza, Siglo XX, Valencia: Editorial Pre-Textos, 2004.
} 
rural architecture and quasi-virginal culture of the island-like Capri for many in Italy, the values of modernity. ${ }^{6}$

On October 25, 1930, Sert, Josep Torres Clavé, José Manuel Aizpurúa, Fernando García Mercadal and others officially launched the group GATEPAC (Grupo de Artistas y Técnicos Españoles Para la Arquitectura Contemporánea) as the Spanish branch of CIAM and the publication of their periodical Arquitectura Contemporanéa or A.C. ${ }^{7}$ The editorial, published in the first issue (1931), reflected the ambiguity of the group's position. On the one hand, it advocated that the new architecture was the fruit of a new spirit "which annuls customs and traditions" and thus required industrialization and mass production; on the other hand, it claimed the importance of the southern vernacular and climate by making direct reference to the Mediterranean "terraces, awnings, flown slabs, screened light" in contrast with the "large glazed areas" of northern architecture. ${ }^{8}$ A double page showing photos of the fishermen's village of San Pol de Mar in relation to J.P. Oud's row houses at the Weissenhofsiedlung in Stuttgart made those positions visually explicit. The same year Mercadal published La casa popular en España, an important book that discussed most regional vernaculars of the country and prolonged Sert's reflections on the modernity of the vernacular. ${ }^{9}$ A.C. would increasingly popularize this theme by devoting many pages to the analysis of vernacular buildings and streets, a project that culminated with the issue 21 dedicated to the rural architecture of Ibiza.

In the same issue $\mathrm{n}^{\circ} 1$ of A.C., the GATCPAC criticized the exponential and up hazard expansion of Barcelona. They suggested the organization of a competition, but the latter did not happen. Nevertheless, the group, which maintained close political contacts with Francesc Macià, President of newly declared Republic of Catalonia, started to work almost immediately on a master plan for Barcelona in collaboration with Le Corbusier. ${ }^{10}$ As the master had already written in 1928, "Barcelona is one of the most beautiful cities in the work, one must make it even more worthy of admiration. Hire me, I will be very happy to be useful to you."11

The Plan Macià as it came to be known developed in multiple phases from 1932 and 1936, and a first comprehensive version, published in $\mathrm{n}^{\circ} 13$ of A.C., was presented to the public in 1934 on Plaza de Catalunya, with big panels and

\footnotetext{
${ }^{6}$ See Michelangelo Sabatino, "The Politics of Mediterraneità in Italian Modernist Architecture," in Modern Architecture and the Mediterranean, and The Politics of Ordinary Things: Italian Modernism and the Vernacular, Toronto, University of Toronto Press, 2009.

${ }^{7} A$.C. was officially the periodical published by the Catalan section of the group, the GATCPA. For a synthetic understanding of the group, see A.C.: la revista del GATEPAC, 1931-1937, Madrid: Museo Nacional Reina Sofía, 2008.

${ }^{8}$ See A.C., n ${ }^{\circ} 1,1930-31$, p. 13.

${ }^{9}$ Fernando García Mercadal, La casa popular en España, Madrid: Espasa-Calpe, 1930; reprinted: Barcelona, Gili, 1981. On page 54 dedicated to the Mediterranean island of Minorca, Mercadal wrote: "Mahón, which is all geometry, might easily fulfill the aspirations of the most fanatical Cubists."

${ }^{10}$ Ibidem, pp. 20-21.

${ }^{11}$ Quoted by Salvador Tarragó Cid, "El Pla Macià o La Nova Barcelona, 1931-38," in Quaderns, nº 90, p. 26.
} 
a huge $180^{\circ}$ diorama, designed with Le Corbusier. ${ }^{12}$ (Figure 2) In the CIAM tradition, the elaboration of the plan started from a rigorous critique and analysis of the urban development of Barcelona and of the living conditions of large segments of the population, not only within the historic center but also within Ildefons Cerdà's Ensanche, the old but rapidly industrializing villages on the outskirts of the $19^{\text {th }}$ century grid, and the exploding periphery. The group was equally very critical of the Garden City concepts that were developing quickly around Barcelona, "a form of urban development which was the fruit of a culture, a climate... totally distinct from the Mediterranean one." 13

Figure 2. Le Corbusier and GATCPAC. Details of the Plan Macià, Barcelona, 1933. (C) José Luis Sert, Can Our Cities Survive?, Cambridge, The Harvard University Press, 1942

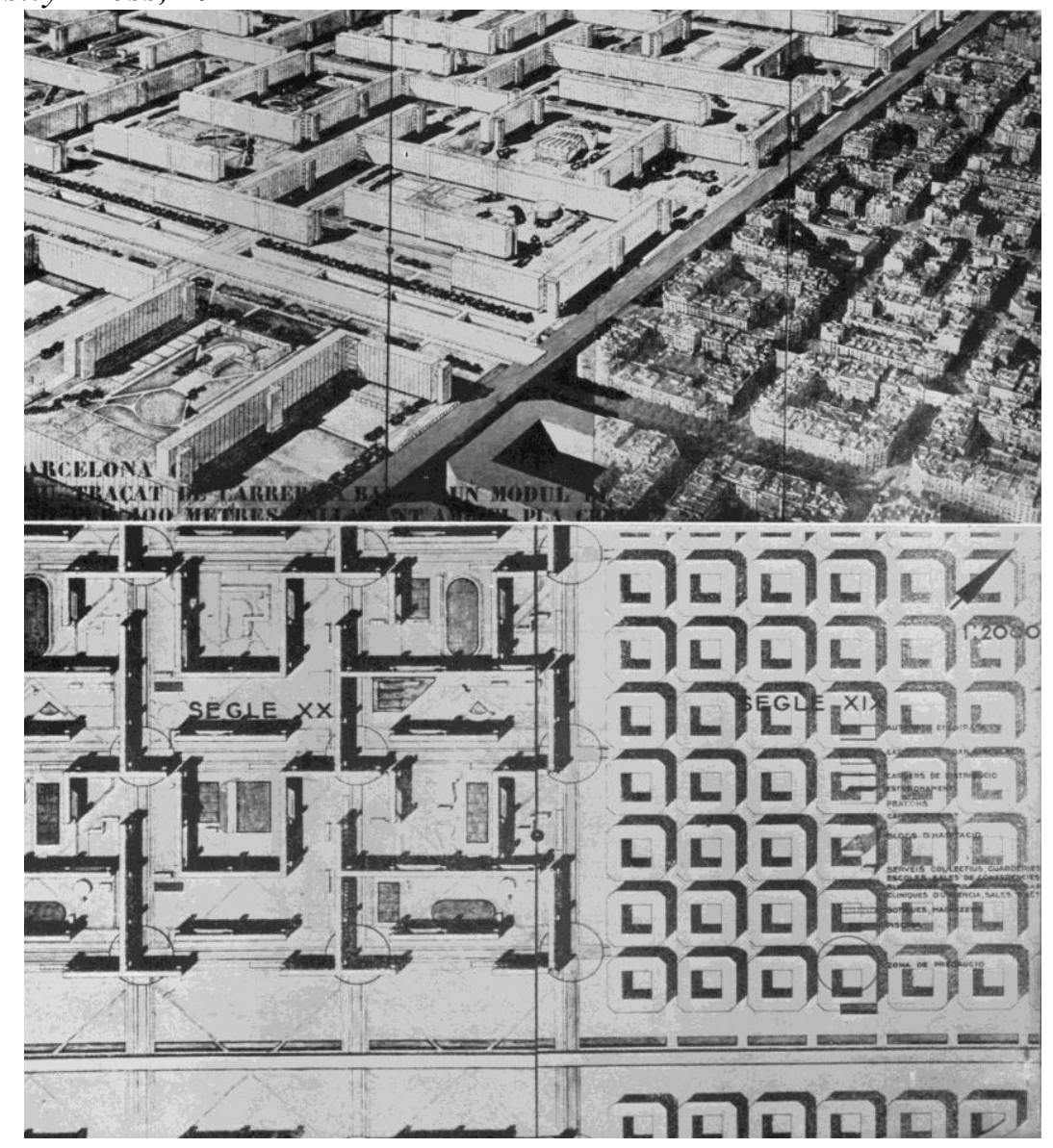

Overall, the Plan was organized around five principles and objectives: urban renewal; a new expansion strategy beyond the Cerdà grid; zoning at the

\footnotetext{
${ }^{12}$ See A.C., no 13, 1934, pp. 14-28. Also see Tarragó Cid, op. cit. \& "El Plan Maciá, sintesis del trabajo del GATCPAC para Barcelona, in $2 c$-Construcción de la Ciudad, $\mathrm{n}^{\circ}$ 15-16, 1980, pp. 68-85;

${ }^{13}$ Tarragó Cid, "El Pla Macià,” p. 25.
} 
metropolitan scale; the creation of a "city of leisure" at the edge of the sea; reform of housing regulations. The urban renewal (saneamiento) involved the historic center on both sides of the Ramblas, with an emphasis on the Raval and Barrio Chino. Even though the architects admitted earlier that the center should have been destroyed and rebuilt, they were aware, under the Republican regime, of the social conditions of the neighborhoods and thus proposed what could be qualified as "careful clearance." The idea was to selectively target the most derelict blocks (both from a social and housing point of view), demolish them and replace them by public spaces like parks, squares, and public equipment: "It is necessary that the residents of the historic center be given more sun, air, light, and a vision of space and trees; in one word, it is necessary for them to reestablish contact with nature." 14 At the same time, the authors heavily criticized the Municipality's plan to open new streets and avenues within the historic center and, in particular, the so-called Via C from the Cathedral to Via Layetana:

"We believe... that to facilitate the contemplation of monuments from new points of view and to extricate them from the neighboring buildings is a dangerous experiment, today abandoned universally and which has failed more than once.... The concept of creating a connection street between the monuments appears to us like the second part of the famous project "Barcelona Gothic," which was rejected by all.... It is preferable to accept the actual environment made up of the superposition of styles of different periods." 15

GATCPAC's strategy of limited and targeted demolitions, coupled with their denunciation of the isolation of monuments, stand out as one of the most interesting aspects of the Plan Macià. For those architects, monuments only made sense in relation to their urban and social context and the old Haussmanian strategy had to be abandoned. ${ }^{16}$ As the group's architects asserted that their criticism implied "more respect for the past" than the official policy, they were also taking their distance from the CIAM theses and the soon to be published Charter of Athens. This was a radical departure from the concept of tabula rasa that CIAM would later advocate and certainly reflected the intensity of social life in the city - and an aspect that has not been often discussed in the history of modernist urbanism. To some extent, I would argue that they expressed a Southern-Mediterranean-vision of the modern city against the prevalent northern one as inscribed in CIAM's tenets.

The second objective of the Plan Macià resulted directly from the critique of Cerdà's Ensanche whose original design and concepts (two-sided blocks, low density and high proportion of gardens, open blocks for public structures)

\footnotetext{
${ }^{14}$ Tarragó Cid, "El Plan Maciá, sintesis,” p. 77.

${ }^{15}$ Ibidem. The GATCPAC's attack against the proposed Via C created such a political problema that they were obliged to remove one of their panels in the exhibition of 1934 .

${ }^{16}$ Ibidem, p. 75. It must be noted that the Plan Macià involved the complete demolition of the Barceloneta neighborhood.
} 
had been turned over and perverted by real estate speculation and increased density. In order to avoid the expansion of the Cerdà block beyond the limits of the plan, the GATCPAC presented a planning alternative based upon a new typological and morphological module that combined nine Cerdà blocks of $133 \mathrm{~m} \times 133 \mathrm{~m}$ together to form a new grid of $400 \mathrm{~m} \times 400 \mathrm{~m}$ to be deployed on the edge of the existing Ensanche and outside villages. This strategy was, according to the group, necessary to limit the size of the city expansion while increasing the density beyond 1000 residents/ha (i.e., twice the density of the actual Ensanche). They wrote:

"It is necessary to concentrate the city: modern urbanism must fight against the concept of garden city and the cities in continuous expansion." 17

Adopting the system of Le Corbusier's redents at the large scale, GATCPAC placed itself again in contraposition with the rigidity of CIAM's schemes. They refused the simplistic strategy of parallel housing bars and implicitly advocated an urban structure that, albeit totally new, may have been able to establish the public spaces necessary to the Mediterranean way of life and, in this case, the concept of the patio at a large scale.

Expectedly, the plan also included the establishment of a zoning at the metropolitan scale. Beyond the many diagrams, two urban/architectural projects made that strategy visible within the landscape. First, as can be seen on the diorama, the Plan proposed an administrative and business center to be established as three tall cruciform towers set into a new park at the edge of the bay and harbor. It is important to point out that, in spite of its dramatic impact, that Civic center involved relatively limited destruction as it was designed, in fact, to reoccupy the water edge by eliminating the railroad and creating an express road and a huge park. Unavoidably, this large-scale zoning relied on a new highway system that involved significant widening of important arteries such as the Gran Vía. Linked to the new metropolitan zoning but presented as an autonomous project within the Plan Macià was the planning of a recreation city to the south of Barcelona along the beach of Castelldefells. "La Ciudad de Reposo que necesita Barcelona," published in details in the issue $\mathrm{n}^{\mathrm{o}} 7$ of $A . C$., was an ambitious plan primarily targeted to the working and middle class, that included hotels, organized beaches and bath complexes, residential areas of cabins or small vacation houses, and other sport infrastructures. The vacation city was a couple of miles long and connected by trains, buses, and a highway terminating in the Gran Vía. All buildings were dispersed and connected by the beach and various nature trails in order to respect the ecologically sensitive pine area. The overall goal was "not to create a fashionable beach but rather a

\footnotetext{
${ }^{17}$ Ibidem, p. 73.
} 
fundamentally democratic path to resolving the social needs of the middle- and working class." 18

Figure 3. Josep Torres Clavé, José Luis Sert \& Joan Baptista Subirana. Plans of Casa Bloc, Barcelona, 1932-36. (C) A.C., $n^{\circ} 11,1933$

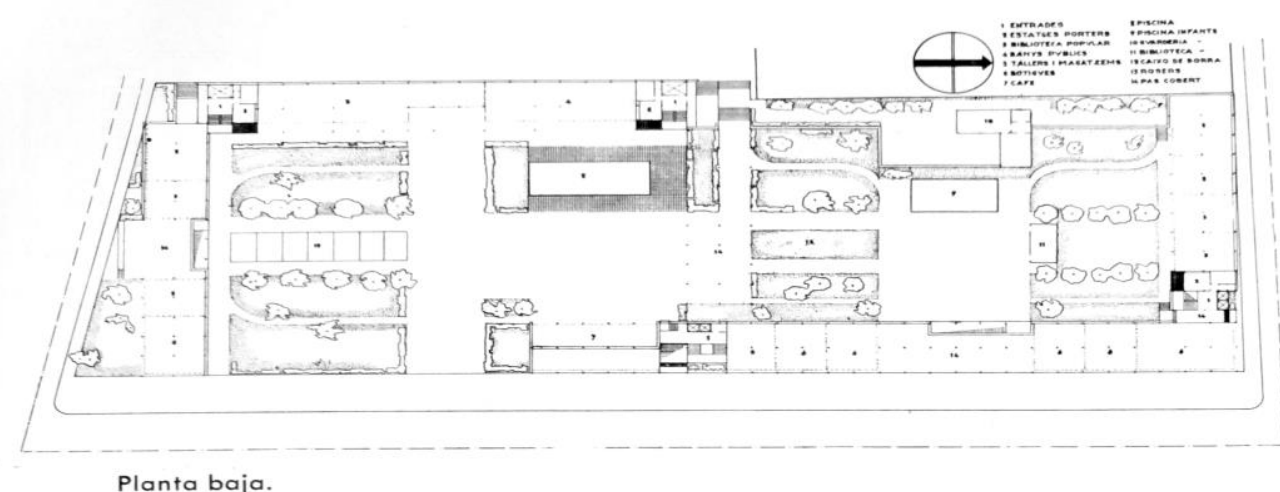

Planta baja. Entradas. 2 Viviendas porteros. 3 Biblioteca popular. 4 Baños públioos. 5 Talleres i almacenes. 6 Tiendas. 7 Café
8 Piscina. 9 Piscina infantil. 10 Guardería infantil. 11 Biblioteca. 12 Coiones de arena. 13 Rosaleda. 14 Paso cubierto

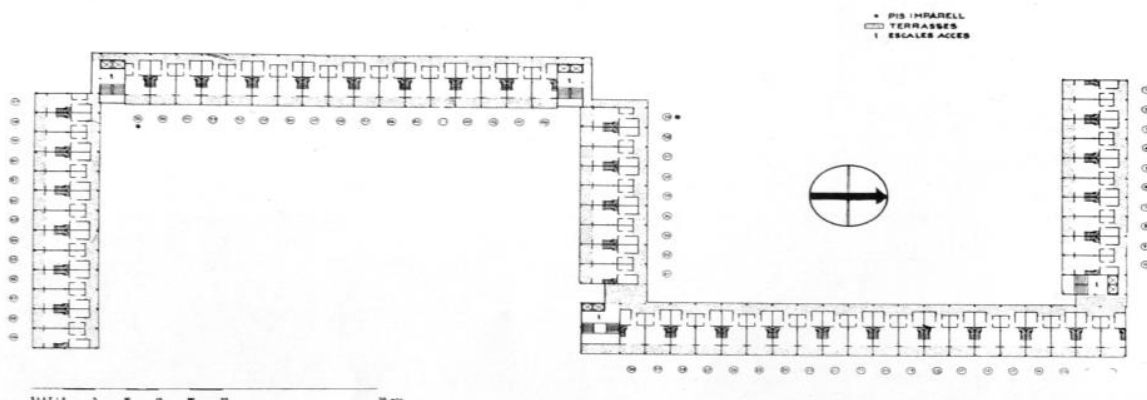

Planta pisos. Planta inferior de las viviendas con los corredores de acceso.

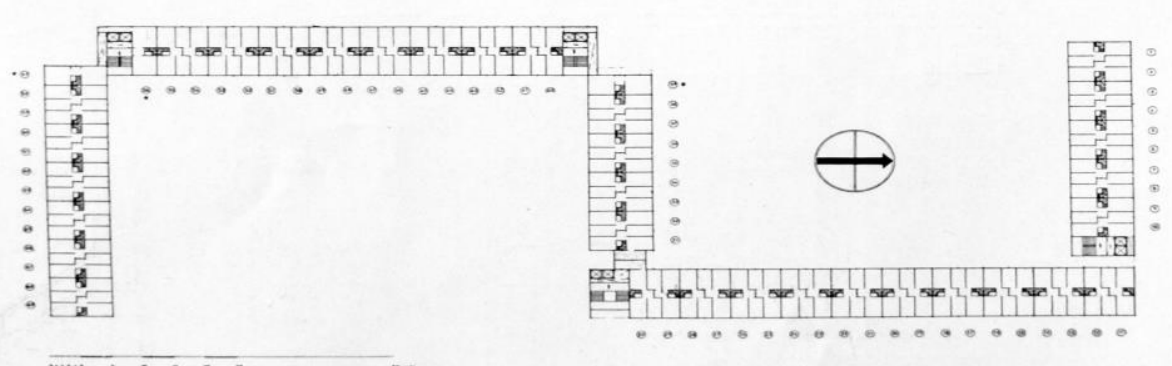

Planta pisos. Planta superior de las viviendas, con los dormitorios.

Bloque de viviendas obreras que se construirá en Barcelona por el Instituto contra el paro forzoso. - Proyecto del Gatepac (G. E.)

$22-$

Last but not least, the Plan Macià proposed a radical reform of the housing regulations in order to require cross-ventilated spaces, eliminate the small

${ }^{18}$ Ibidem, p.81. 800,000 people were members of the Cooperativa de la Ciudad de Reposo y Vacaciones de Castelldefells (unions, cultural and sport associations, etc.). See A.C., $\mathrm{n}^{\mathrm{o}} 7$, 1932, pp. 24-31. 
internal ventilation patios, and thus reduce the typical width of the units. All of these were necessary to adopt the new module of nine Cerdà blocks for the expansion of the city. They were also instrumental in the design of the Casa Bloc whose construction was underway (1933) under the direction of architect Josep Torres Clavé in collaboration with GATCPAC members José Luis Sert and José Baptista Suberino. ${ }^{19}$

Figure 4. Josep Torres Clavé, José Luis Sert \& Joan Baptista Subirana. Casa Bloc, Barcelona, 1932-36. (C) José Luis Sert, Can Our Cities Survive?, Cambridge, The Harvard University Press, 1942

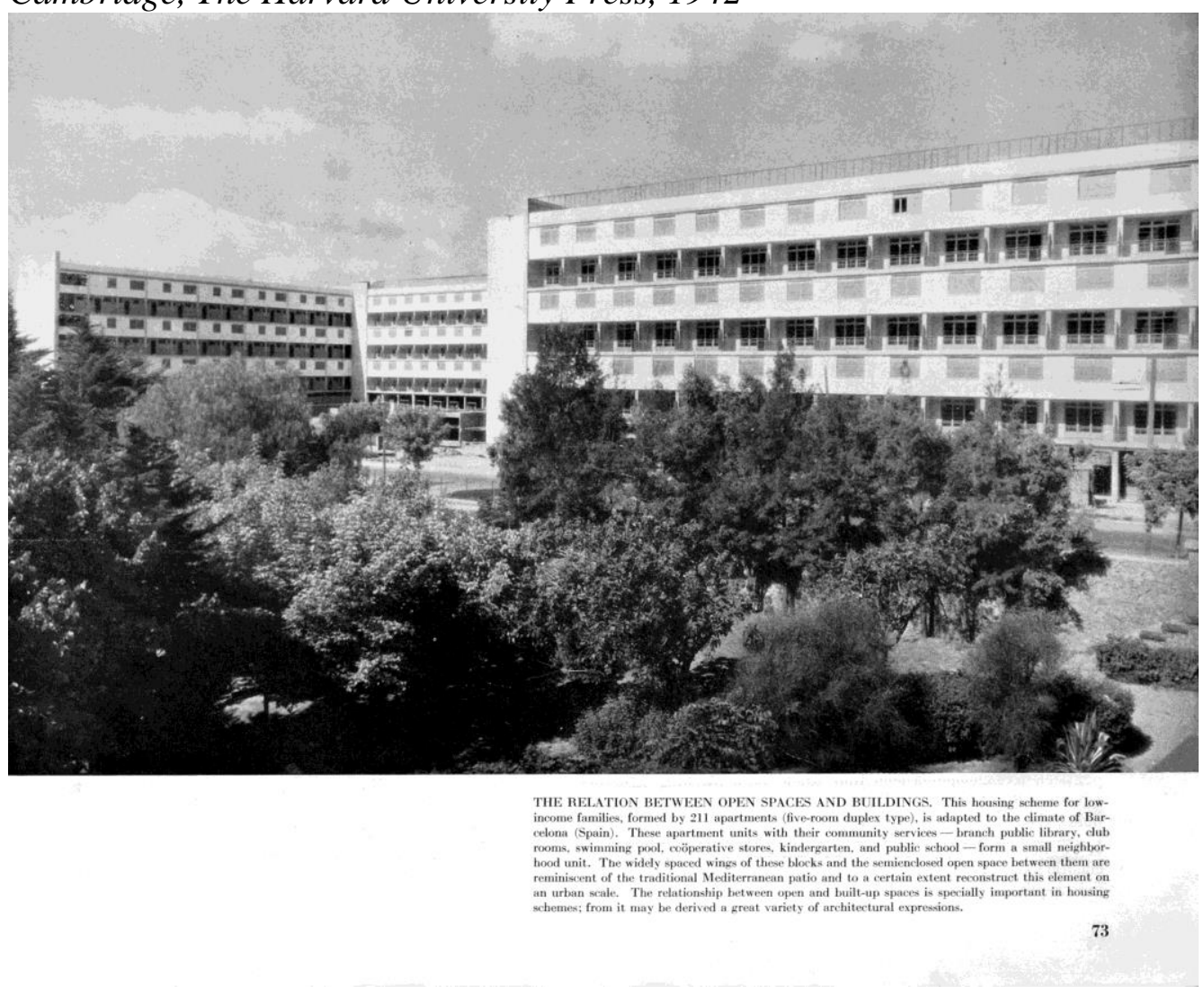

Built from 1932 to 1936, the Casa Bloc was an experimental social housing project for industrial workers located to the northeast of the Ensanche in the Sant'Andreu neighborhood. As described by the architect in the A.C. $\mathrm{n}^{\circ} 11$, "the Casa [Bloc]... constitutes a first experiment for the Republican revolution: a new plan and type of social housing projects that will come out as results of the new social structure of the country." ${ }^{20}$ The parcel was 170 meter long and 70 meter wide, along a street 30-meter wide. It was much smaller than the module proposed in the Plan Macià, but the architects adopted the same

\footnotetext{
${ }^{19}$ On Clavé, see the special issue of $2 c$-Construcción de la Ciudad, $\mathrm{n}^{\circ}$ 15-16, 1980.

${ }^{20}$ See A.C., n ${ }^{\circ} 11,1933$, p. 22. Also see Carolina B. García and Josep M. Rovira, Casa Bloc, Barcelona: Mudito \& Co, 2011; Salvador Tarragó Cid, "Revendicació de la Casa Bloc," Quaderns, ${ }^{\circ} 140$, pp. 41-43.
} 
concept of "redents" that characterized their vision for the expansion of Barcelona. The S-shaped linear structure was organized around two large planted open patios, one toward the street and the other toward the back (Figure 3). The whole structure was articulated around four staircases and elevators with outdoor distribution corridors every two floors. Every section of the project consisted of 3 levels of cross-ventilated apartments designed as double-level units, and reaching a density of 1140 residents per hectare with outstanding environmental conditions. The living/kitchen level of every duplex was 4-meter wide which corresponded to the width of the structural system, whereas the switching of interior partitions off the grid on the second level allowed to provide three relatively generous bedrooms in each unit.

Like the Plan Macià, the Casa Bloc did break away from a certain northern orthodoxy. José Luis Sert presented this project in his book Can Our Cities Survive?, published in 1942 in the United States following his voluntary exile during the Civil War (Figure 4):

"This housing scheme for low-income families, formed by 211 apartments (five-room duplex type), is adapted to the climate of Barcelona (Spain). These apartment units with their community services... form a small neighborhood unit. The widely spaced wings of these blocks and the semi-enclosed open space between them are reminiscent of the traditional Mediterranean patio and to a certain extent reconstruct this element on an urban scale. The relationship between open and built-up spaces is especially important in housing schemes: from it may be derived a great variety of architectural expressions.",21

Moreover, even though the Casa Bloc was built on pilotis to help with ventilation of both streets and patios, important sections of the ground floor were reserved for retail, social services, etc. The plans published in A.C. indicated the extent of traditional mixed-use spaces integrated within the ground floor plan of the project. In so doing, the architects emulated-in the modernist language - the functions of traditional Madrid block (manzana), or, as Sert wrote as a "neighborhood unit": concierge housing units, public library, public baths, workshops, shops, café, swimming pool, day-care center, and other gardens. Part of that program reflected the social ambitions of the second but short-lived Republican government, but beyond its ideological implications, it also emphasized that the Casa Bloc was an urban alternative to the traditional block. This attitude was not an exceptional one: the same issue

\footnotetext{
${ }^{21}$ José Luis Sert, Can Our Cities Survive?, Cambridge: Harvard University Press, 1942, p. 73. The book was an attempt to introduce the Charter of Athens to the American profession and public. Ten years after in 1953, Sert and his partner Paul Lester Wiener published the famous article "Can Patios Make Cities," in Architectural Forum, Aug. 1953, pp. 124-[131], where they advocated the use of the patio at the scale of the city (civic center), the neighborhood (plaza), and the house (patio). Also see Carola Barrios, "Can patios make cities? Urban traces of TPA in Brazil and Venezuela," in ZARCH. Journal of interdisciplinary studies in Architecture and Urbanism, $\mathrm{n}^{\circ} 1$ (Las trazas del lugar / Traces of place), 2013, pp. 70-81.
} 
of A.C. 11 presented a revised Cerdà block whose urban characteristic-size, enclosed perimeter, mixed uses-were maintained and modified at the same time through the use of pilotis and sections of blocks set up at ninety degrees. The capacity of the GATCPAC group to mix modernity and tradition at both the architectural and urban level remains to be studied in details. As Carolina García and Josep Rovira wrote recently in their small monograph Casa Bloc:

"Redents and pilotis anticipate the conceptual scheme that informs the Casa Bloc, a formal scheme that unmistakably has intellectual implications: to take side in history, at the present moment. Against the linear block of the Siedlungen. Against Germany. And also against the enclosed block and the garden city."22

Figure 5. Josep Torres Clavé, José Luis Sert \& Joan Baptista Subirana. Casa Bloc, Barcelona, 1932-36. (C) Photo Jean-François Lejeune

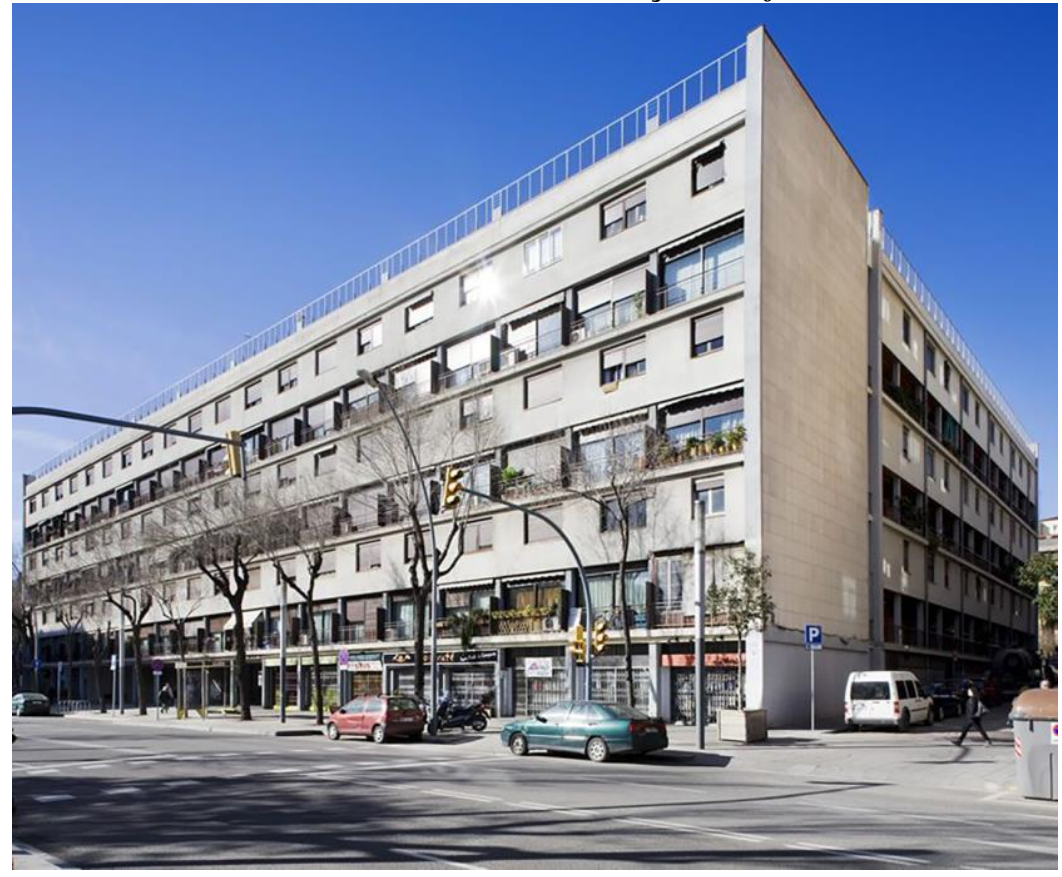

\footnotetext{
${ }^{22}$ Carolina B. García and Josep M. Rovira, Casa Bloc, p. 11. Another project for the Diagonal in Barcelona
} 
The Madrid Plan: Zuazo, Jansen and the Casa de las Flores

... I lived in a neighborhood

of Madrid, with church bells, with clocks, and with trees.

From there I could see

the dry face of Castille

like an ocean of leather.

My house was called

The House of the Flowers, for

they were geraniums in all parts;

it was a beautiful house

with dogs and a lot of kids. ${ }^{23}$...

Born in Bilbao, Secundino Zuazo Ugalde (1887-1971) was one of the most important architects and urbanists to rise in 1920s Madrid until his forced exile by General Franco and his eventual return to Spain in the late 1940 s. $^{24} \mathrm{He}$ graduated in 1912 and worked with Antonio Palacios and Joaquín Otamendi, two eclectic architects whose important work continues to mark the landscape of early $20^{\text {th }}$ century Madrid. Between 1920 and 1927, Zuazo elaborated urban design projects for the interior redevelopment and the expansion of Sevilla, Bilbao and Zaragoza, among other cities - all proposals of indisputable originality and invention within the conventions of the European city. If the intellectual environment of Barcelona was highly influenced by Le Corbusier and his Mediterranean revelation, in Madrid, it was the German world of modern planning and architect-urbanists like Bruno Taut, Otto Wagner, Paul Mebes, Joseph Stübben or Paul Wolf who were the definitive references. ${ }^{25}$ Those German planners and architects pursued the same goals of a better, more humane, more environmentally-friendly city and they had advocated a lot of new ideas such as the so-called "reformed block," i.e., an enclosed block containing a large garden and, in some cases, some public infrastructure inside. ${ }^{26}$ Equally influential were the Viennese Höfe, the abstracted classical architecture of Adolf Loos, and Henrik Berlage's conception of the modern

\footnotetext{
${ }^{23}$ Pablo Neruda, selected lines from "Explico algunas cosas," Residencia en la Tierra, Madrid: Ediciones Cruz y Raya, 1935

${ }^{24}$ On Zuazo, see Lilia Maure Rubio, Secundino Zuazo, arquitecto, Madrid: Fundación COAM, 1987, and the special issue of the periodical Arquitectura, vol. 12, $\mathrm{n}^{\mathbf{0}}$ 141, 1970. Also see Carlos Sambricio, “ Introducción,” Secundino Zuazo, Madrid y sus anhelos Urbanisticos. Memorias, 1919-1940, Madrid: Comunidad de Madrid, 2003, pp.12-134.

${ }^{25}$ See Carlos Sambricio, "Hermann Jansen y el concurso de Madrid de 1929," in Arquitectura, $\mathrm{n}^{\circ}$ 303, 1995, pp. 8-15; also see his very important essay "Zuazo in Caracas: The urbanism of exile in Venezuela 1937," in Planning Perspectives, v. 28, 2013, pp. 51-70.

${ }^{26}$ On the concept of reform block, see Wolfgang Sonne, "Dwelling in the Metropolis: Sitte, Hegemann, and the International Dissemination of Reformed Urban Blocks, 1890-1940," in Jean-François Lejeune \& Charles Bohl (eds.), Sitte, Hegemann and the Metropolis: Modern Civic Art and International Exchanges, London: Routledge, 2009, pp. 249-274; Wolfgang Sonne, Urbanität und Dichte im Städtebau des 20. Jahrhunderts, Berlin: DOM Publishers, 2014.
} 
city where the city block conceived as a whole, rather than the sum of individually built parcels, were to become the main component of modern urban monumentality. In the early 1930s Madrid, "Secundino Zuazo played, along with Leopoldo Torres Balbás... the role accepted by all of master of the younger generation: most prominently, in the controversy over the nature of the classical language or the analysis of rational housing unit." 27

The planning of Madrid had been dominated since 1860 by the implementation of the Plan Castro, but the Ensanche was far from complete and what had been done was in many ways in contradiction with the original plan. Many public spaces were not respected, as the implemented grid privileged traffic and thus eliminated most of the public places programmed by Castro. Moreover, the successive building ordinances from 1864 allowed for a higher density, compensated only by small-scale inner light and ventilation courtyards. Even more important was the fact that there was an unplanned area between the limits of the Castro Plan - known as the Extrarradio - and the edges of municipal Madrid. In 1929, the City of Madrid called a competition to prepare an extensive study of the extension of the city (particularly to the north) and potential reforms of the historic center. Thanks to the intervention of Fernando García Mercadal (founder of GATEPAC, he worked in Zuazo's office for some time), Zuazo associated with the German planner Hermann Jansen. Disciple of Karl Henrici in Aachen, Jansen had won the master plan for Groß-Berlin in 1910 and had in the aftermath been the artisan of various neighborhoods plans of Berlin, as well as abroad. He was also the editor of the important periodical Der Baumeister from 1924 to $1929 .{ }^{28}$

\footnotetext{
${ }^{27}$ Sambricio, "Hermann Jansen y el concurso de Madrid de 1929," p. 8.

${ }^{28}$ Ibidem. There is still no comprehensive study of Jansen's extensive work, with the exception of his work in Ankara.
} 
Figure 6. Secundino Zuazo \& Herman Jansen. Masterplan for Madrid, 192930. (C) Zuazo and Jansen, Anteproyecto del Trazado Viario y Urbanización de Madrid: Zuazo-Jansen, 1929-30, Madrid: COAM, 1986

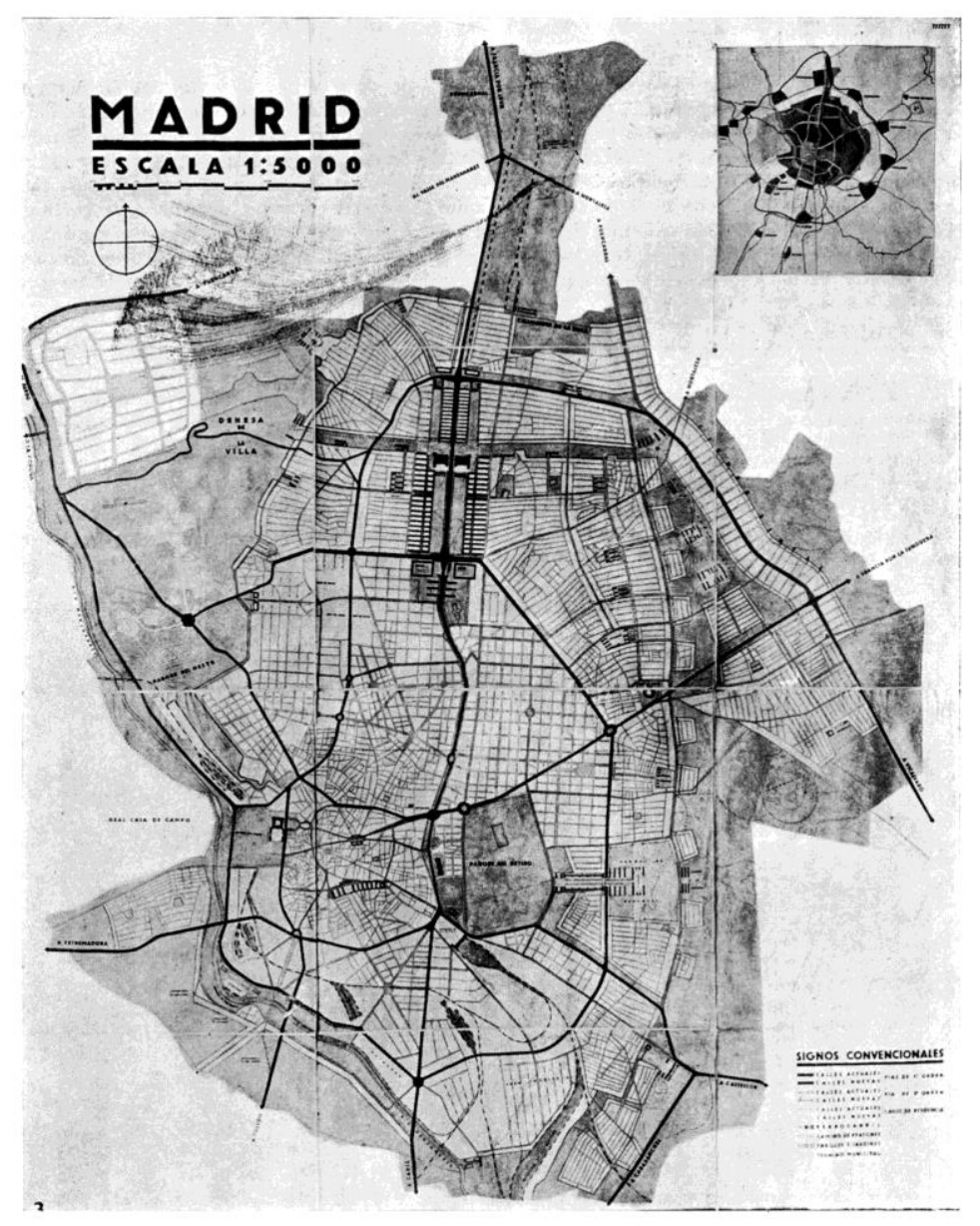

The team Zuazo-Jansen placed first in the competition but the jury headed by German architect Paul Bonatz decided not to designate a winner. The Zuazo-Jansen Anteproyecto del trazado viario y urbanización de Madrid responded best to the preconditions set by the municipal government, i.e., to plan the future of the city in relation to the global traffic, including automobiles, metros and railways, and to the housing needs with an emphasis on "the necessity to study the distinct typologies of housing as generating cells of the urban fabric." 29 In contrast with the Plan Macià, the Anteproyecto clearly limited the extension of the city with the use of a large green belt and "the development of satellite-cities which, new or superimposed on existing urban

\footnotetext{
${ }^{29}$ On the competition, see note 22 and Lilia Maure Rubio, Anteproyecto del trazado viario y urbanización de Madrid: Zuazo-Jansen, 1929-30, Madrid: COAM, 1986, p. xix. The project was partially published in A.C. n², 1931, pp. 24-25.
} 
or rural nuclei would absorb the surplus of urban growth." 30 (Figure 6). In line with international proposals by Jean Claude Nicolas Forestier, Martin Wagner and Jansen himself, the greenbelt was to be connected with existing parks and gardens, in a fully integrated "system of parks." Within the belt, Zuazo and Jansen designed the large-scale armature of the new neighborhoods to be planned in the Extrarradio in a combination of five density zones from 450 residents/ha to single-family houses; all proposed blocks were shaped as variations of long rectangles with large green cores in their centers. The plan also included a series of proposals for the historic center, mainly the widening of radial arteries and the design of an interior ring connecting the Gran Vía to the Opera and Calle Atocha. In addition, a large central market and business district was to be built into phases to the south of the Plaza Mayor. This project, along with another proposal between the Gran Vía and the Plaza Alfonso Martinez, was part of Zuazo's ambitious plan of inner-city reform that he would study and present later. ${ }^{31}$ Both projects involved a significant amount of demolition of the historic fabric - a fact not unusual at that moment of $20^{\text {th }}$ century urbanistic practice and theory-but the proposed solutions were typologically quite inventive for their attempt, in spite of their radicalism, at developing a new urban form in relation to the historic city.

\footnotetext{
${ }^{30}$ Lilia Mauro, introduction to Anteproyecto, p. xxiv. According to Carlos Sambricio, "Zuazo established the outline of the project, and they divided the workload between them. The evidence for this is seen in Jansen's original sketches, found in the Plan Sammlung del Kunstwissenschaft Institut of the Technische Universität in Berlin, as well as drawings located in the Zuazo archive in Madrid's National Library. The Berlin drawings demonstrate how Jansen approached the plan for the outlying districts. He proposed a zoned system for the city, with new industrial districts, a residential district, and a detailed study of how the extension of the Paseo de la Castellana should be conceived. At the same time Zuazo concentrated on alterations to the city center, indicating how to lay out the new infrastructure, as well as analyzing - based on criteria different from those set out by the German - the vision for the Castellana axis." (from Sambricio, "Secundino Zuazo in Caracas: The Urbanism of Exile in Venezuela 1937," op.cit.).

${ }^{31}$ See Secundino Zuazo, "La Reforma interior de Madrid," in Arquitectura. $n^{\circ}$ 7, 1934, pp. 175 206.
} 
Figure 7. Left: First Version of the Extension of the Castellana, 1929-30, by Zuazo \& Jansen. (C) Zuazo and Jansen, Anteproyecto del Trazado Viario y Urbanización de Madrid: Zuazo-Jansen, 1929-30, Madrid: COAM, 1986. Right: Second Version of the Extension of the Castellana, 1930, by Zuazo. () Secundino Zuazo, Madrid y sus Anhelos Urbanisticos. Memorias, 1919-1940, Madrid: Comunidad de Madrid, 2003
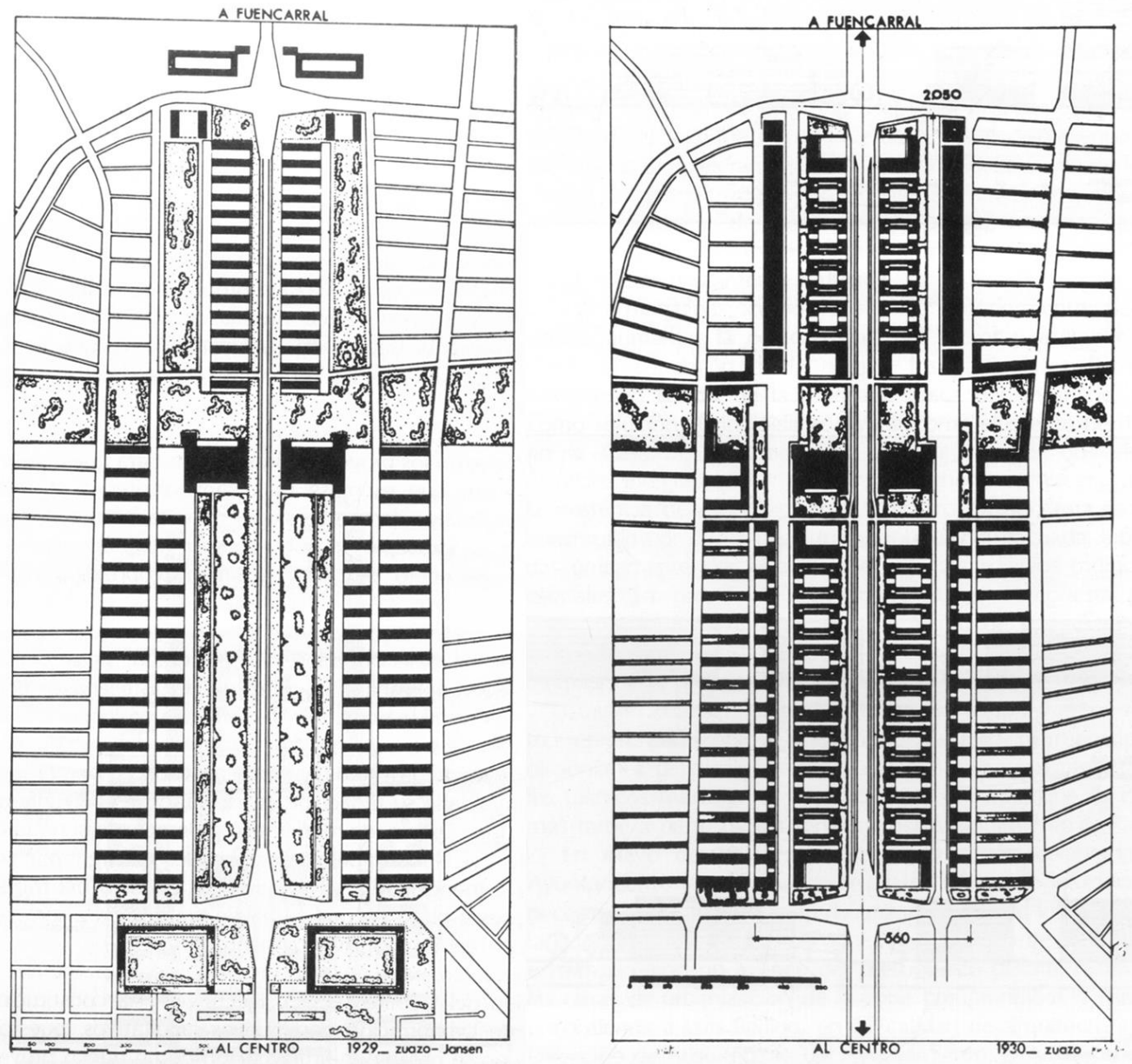
Figure 8. Secundino Zuazo \& Herman Jansen. Perspectives of the First Project for the Extension of the Castellana, Masterplan for Madrid, 1929-30. (C) Zuazo and Jansen, Anteproyecto del Trazado Viario y Urbanización de Madrid: Zuazo-Jansen, 1929-30, Madrid: COAM, 1986
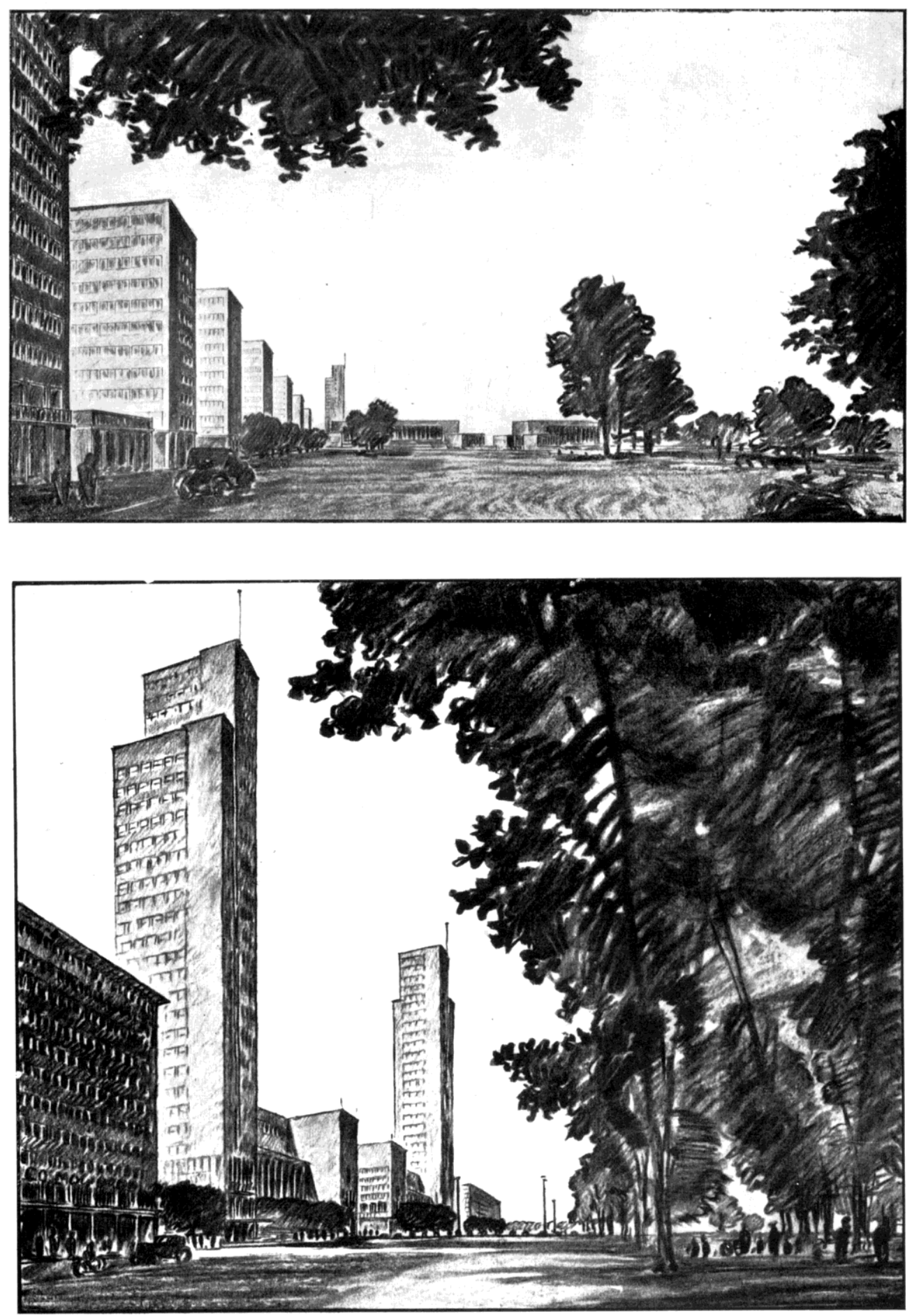

Prolongación de la Castellana. - Perspectiva de los Grandes Conjuntos, en el cruce normal al Gran Paseo. 
The focus of the Zuazo-Jansen Plan was the prolongation of the historic axis Paseo del Prado/Paseo de la Recoleta/Paseo de la Castellana toward the north, a project in discussion for decades but without effective resolution. The first version of the plan presented for the competition in $1929-\mathrm{a} 2.5 \mathrm{~km}$ long project mixing parks and linear parks, public buildings and plazas-had the potential of dramatically impacting Madrid's overall urban form and create a civic and residential pole, comparable in size and spirit with the Paseo del Prado and the Retiro Park, while proposing at the same time a new and modernist urban form for housing. At the center of the project was a 400 meter wide linear park embracing the central roadway boulevard on a length of approximately 1200 meter. At its southern end, at the connection point with the existing Paseo de la Castellana, Zuazo and Jansen designed two large courtyards blocks whose use was not determined; at its northern end, two large public buildings marked the intersection with another wide E-W green boulevard. Beyond this intersection the extended Paseo was reduced in width to about 100 meters (Figures 7, 8).

Even though it may suffer from excessive symmetry and may have been too wide to be fully activated, this monumental composition at the scale of the whole city, both traditional and modern, could have been one of the most impressive in a European city. It was overall, in spite of its traditional axial monumentality, a more "modernist" scheme than what GATCPAC had proposed in any section of the Plan Macià-almost an anticipation of Lúcio Costa's conceptual scheme for Brasilia. Indeed, twenty parallel 12-story bar buildings connected by low structures flanked the wide Paseo on each side. At the intersection with the E-W green, Zuazo and Jansen planned two large cultural buildings, which would have appeared in the landscape by their attached 25-story thin towers. Moreover, in a bold but rational infrastructural move, they proposed to build an underground tunnel under the extended Paseo de la Castellana between the two main train stations of Chamartín to the north and Atocha to the south.

In 1929, Zuazo, who intended to be a business partner in the execution of the Castellana project, criticized the decision to entrust the development to a Municipal Technical Office. Yet, a couple of months later, the Mayor of Madrid, the Marquis de Hoyos, asked the Madrid architect to come back to the project and revise the proposal for the prolongation of the Castellana by making it more profitable both for the city and private real estate interests: parks were to be reduced and the density increased with the use of a new type of block with a large interior courtyard; at the same time, Zuazo pleaded for the insertion of social housing in the overall scheme. The revised project, without the participation of Jansen, maintained the large-scale civic center in the middle of the development, whereas a more traditional urban fabric lined up both sides of the Paseo reduced in width to 120 meters. Like in Barcelona with the Casa Bloc, the block type proposed by Zuazo was being built at exactly the same moment in the Ensanche of Arguëlles to the western side of the city near the Moncloa - the Casa de las Flores. This type of block implied a more continuous urban front along the extended Paseo de la Castellana and thus 
supported a more traditional vision of urban space, one that would have more appropriate to host the mixed uses that were fundamental for a successful urban life along the Paseo. ${ }^{32}$

Figure 9. Secundino Zuazo. Casa de las Flores, Diagram Plan and Axonometric View, 1929-33. (C) Lilia Maure Rubio, Secundino Zuazo, Arquitecto, Madrid: Fundación COAM, 1987
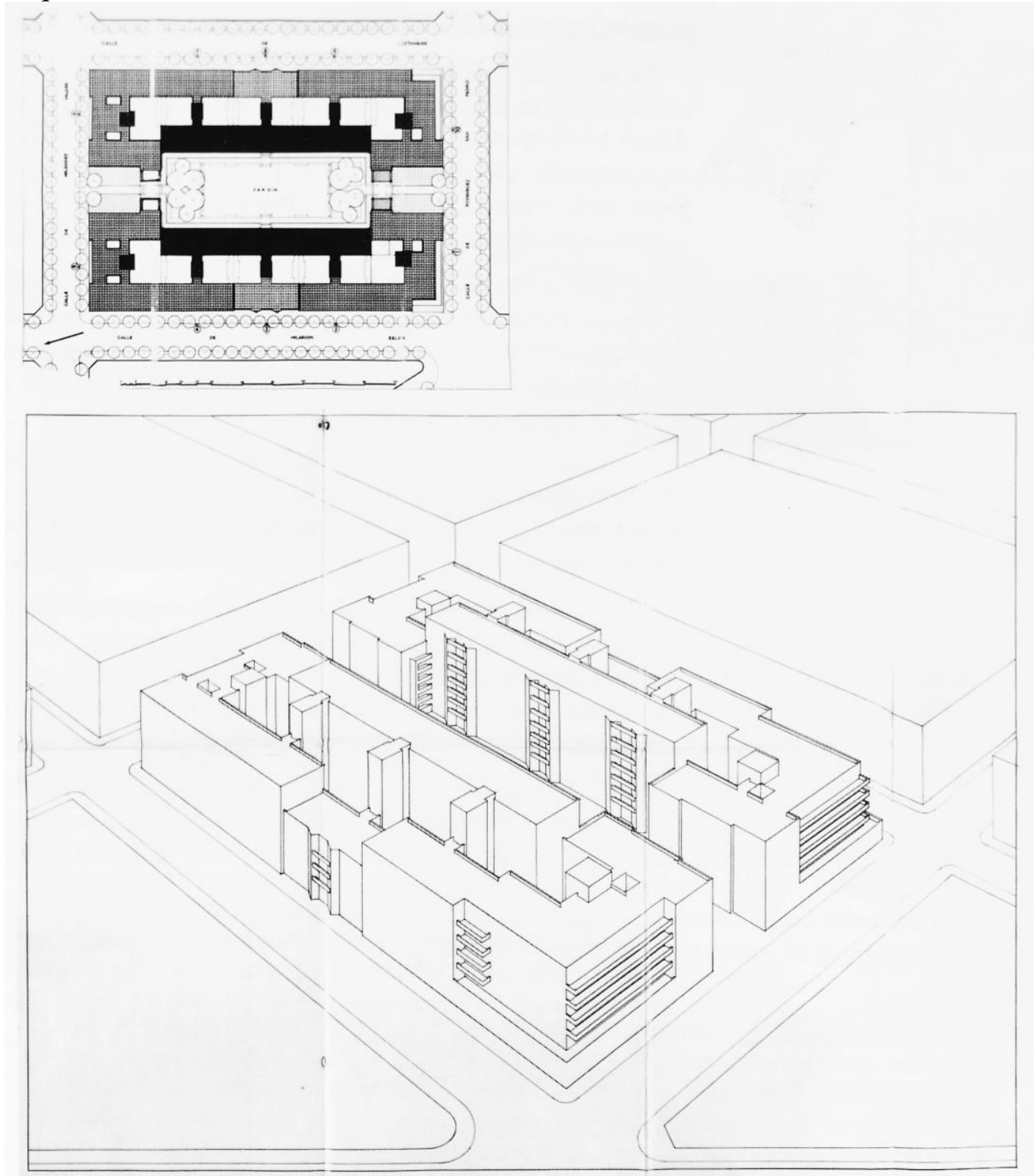

\footnotetext{
${ }^{32}$ Sambricio mentions in the essay "Secundino Zuazo in Caracas" that the Spanish architect intended to use the Casa de las Flores type in the competition proposal but Jansen convinced him to adopt the more modern proposal. Carlos Sambricio, "El bloque Las Flores, de Secundino Zuazo," in RA, Revista de Arquitectura, nº15, 2013, pp.23-34; "Antología de textos sobre la Casa de las Flores" in Quaderns, $\mathrm{n}^{\circ}$ 150, 1982, pp. 86-87.
} 
The original block or manzana designed in the Plan Castro of 1860 left half of the block area free of construction and proposed to establish a large central patio to promote density with adequate ventilation and green spaces. Yet, in 1864 already, height had been increased from to three to four floors with mandatory ventilation patios while the percentage of open space had been reduced to thirty-five and in some smaller cases to twenty per cent. ${ }^{33}$ Moreover, given that a typical manzana would be built as an assemblage of individual properties, the resulting spaces were more often than not inadequate for residents' uses. For the Casa de las Flores, Zuazo went back to Castro's original concept and percentage of open space: he organized the block in two parallel sections around a large public central patio, open on both short sides of the rectangle. The block/building was a complex massing of six sections with four, six or eight floors depending on their location and the neighborhood ordinances. The two parallel sections consisted of five individual apartment houses - each organized around a very large light and ventilation patio. The nuclei of vertical circulation were set up as bridges across the ventilation courtyards, thus providing airy and well-ventilated vertical circulation spaces and allowing for larger and better lighted apartments on both sidesinterestingly, this new system has become a familiar feature of Madrid housing from the postwar decades and is quite popular in contemporary construction (Figure 9). Overall, the Casa de las Flores contained 248 apartments varying from 88 to 170 square meters, i.e., originally hosting up to 1475 residents in the block; a variety of retail areas, including a café known for important tertulias (social and/or literary gatherings), provided all necessary services to residents and neighbors.

As built, the Casa reflected Zuazo's two main objectives: firstly, to remedy the problems of the Ensanche, i.e., to redefine the block versus the lot in the manner advocated by his German mentors and Hendrik Berlage, and thus provide more hygienic and better ventilated apartments; secondly, to propose a new typology for the extension of the city that would reflect a new social concept of "convivencia" or "living together." In his manuscript notes, the architect described, in a quite modern language that recalls both Le Corbusier and Walter Gropius, the functional aspects of his project:

"Projected under architectural inspirations and social concepts prevalent in our time.

The group of houses is a huge mass of construction, an "Escorial" in pink brick. It is designed with strict sense of the function and the decorative elements are actually functional elements.... A very rational art of handling the brick, to establish rhythms and decorative

\footnotetext{
${ }^{33}$ On the Plan Castro, see Carlos María de Castro, Memoria descriptiva del Ante-Proyecto de Ensanche de Madrid (con estudio preliminar de Antonio Bonet Correa), Madrid: COAM, 1978. Also see the excellent document at http://www.madrid.es/UnidadWeb/Contenidos/Publi caciones/TemaUrbanismo/PlanCastro/plancastrocorr.pdf.
} 
series with different orders, is what gives particular grace to this set of large buildings together.

The architect looked exclusively function, and has achieved a logical and rational set, which strongly impressed by the admirable play of volumes of construction." 34

Yet, at the same time and like Clavé at the Casa Bloc, Zuazo combined the languages of modernity and tradition to produce a work of architecture and urbanism that strongly belonged to Madrid, its past, its present and its future. The facades of the four corners of Casa de las Flores displayed the Madrilenian brick, whereas the eight-floor recessed sections on both N-S sides, the interior courtyards, and all facades facing the garden-like patio at the center of the block were stuccoed. Most remarkable were the two apartment houses on the southern corners of the complex: their deep balconies, where flowers grow, are reminiscent of the vernacular interior courtyards or distribution terraces visible in Triana, Sevilla, or even the corrales - the open air theaters that used to be visible across Renaissance and Baroque Spain. Zuazo made direct reference to those traditional vernacular elements:

"When analyzed, one notices gracefully designed elements that were never exotic in Spain, but, on the contrary, reflect an ancient traditional lineage.

Arcades along streets, as in many Spanish towns and cities. Garden courtyard, stepped terraces, balconies and sunrooms. Chromatic surfaces. $" 35$

\footnotetext{
${ }^{34}$ Carlos Sambricio, "El bloque Las Flores," p. 32.

${ }^{35}$ Ibidem. Corrales originated from courtyard performances, and were constructed within rectangular courtyards enclosed by buildings on three sides. The stage was raised with a permanent backdrop, and a patio for standing spectators was placed in the upper levels.
} 
Figure 10. Secundino Zuazo. Casa de las Flores, Madrid. (C) Photo: JeanFrançois Lejeune

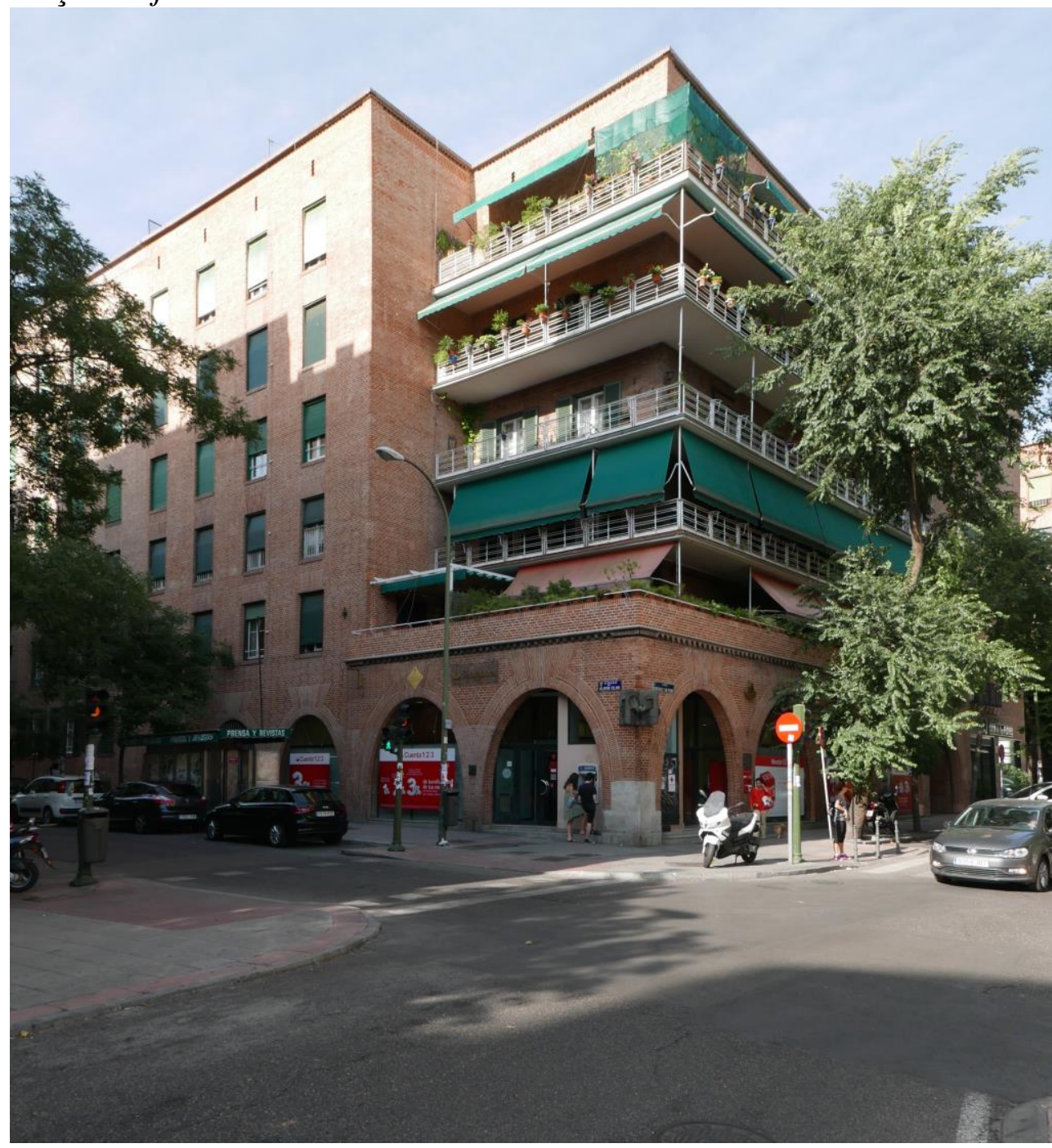

In 1931, with a serious economic depression looming over Spain, the Minister of Public Works of the Second Republic, Indalecio Prieto, launched the Plan Nacional de Obras Públicas, which included, thanks to Zuazo's last minute and energetic intervention, the creation of the North-South railway connection and the construction of an important underground station under a new ministerial complex to be located at the southern entrance of the prolonged Castellana. The Nuevos Ministerios as the area came to be known matched Zuazo's original vision of a new civic district to the north of the capital. Pressed by the complex political situation, he embarked on the gigantic task with a very basic program for four ministries. The scheme was articulated around two grand perpendicular squares, conceived as lonjas that would function as "a replica of Philip II's Escorial." ${ }^{36}$ Long covered arcades protected

${ }^{36}$ The lonja is a traditional market or warehouse structure, usually long and thin in width. See Lilia Maure Rubio, "The New Ministries in Madrid: an Architectural Proposal by Secundino 
the squares from the heavy street traffic_- "arcades like those built throughout history, arcades of modern materials, various stones and bricks, but used with elegant quality, neither with applied materials nor in the traditional way." $" 37$ Zuazo worked on the design and construction until the Civil War started. When he left for Paris in the early 1938, the project was well advanced. ${ }^{38}$

\section{Conclusion: Doom and Rebirth}

The Civil War put a definitive end to the potential implementation of the master plans: no element of the Plan Macià was ever implemented and in Madrid the Nuevos Ministerios were eventually completed in the 1940s without the participation of their original architect. In 1943, the Franco regime transformed the Casa Bloc in a residence for military personal and police and closed the patio facing the street with a banal slab block, a clear attempt at symbolically deny the recent past and the socio-political implications of the Republican-era project. In 1997, the Diputación de Barcelona and the City of Barcelona embarked on the renovation of the Casa Bloc. The slab, which had come to be known as the Bloque fantasma was eventually demolished in 2008 and the whole complex re-inaugurated.

The Casa de las Flores hosted important residents such as Pablo Neruda when he became Consul of Chile in 1934. Situated at the edge of the frontline between the Republican and the Nationalist armies, the block was partially bombed and occupied by military troops and hospital. It was reconstructed as it was in the 1940s and continues to be an important reference for modern housing and living in Madrid. In the words of architect Juan Cano Lasso,

"[the Casa de las Flores] could have been an excellent model for the urban renovation of Madrid; it would have created a new urban fabric, lighter and more open, a synthesis between the modernist bar and the traditional closed block, with a network of interior gardens.

Zuazo," Composición Arquitectónica - Art and Architecture, no 3, June 1989, pp. 103-136. Quoted by Rubio from the Papeles inéditos de Secundino Zuazo, p. 108-109, now available in Secundino Zuazo, Madrid y sus anhelos Urbanisticos. Memorias, 1919-1940, Madrid: Comunidad de Madrid, 2003.

${ }^{37}$ Ibidem, quoted p. 116. As for the Castellana project, Sambricio writes in "Secundino Zuazo in Caracas": "The full concept of the Paseo de la Castellana was restarted again in 1939 when one of Zuazo's collaborators (Pedro Bidagor, a man trusted by the Franco govemment) manipulated and corrupted the original concept and attempted - like Speer in Berlin - to establish a new city of Power as opposed to one of Social Peace, including (on Wemer March's advice) a large stadium where Franco's regime could hold political gatherings." For more on this complex history, see the extensive literature on the Plan Bidagor.

${ }^{38}$ Zuazo arrived in Paris in 1938, fleeing from the threats of anarchist groups who aimed to seize some of his properties. He left Franco's Spain, loyal to the Republican government until the very end. Refusing to collaborate with the regime, he was exiled for four years in the Canarias Islands. After his return to Madrid, his professional career never reached the quality and intensity of his pre-Civil War period. 
Unfortunately, the ordinances needed to be changed and they were not, continuing to promote the lot-based real estate development."

\section{Bibliography}

2c-Construcción de la Ciudad [Construction of the City] 15-16 (1980): special issue Josep Clavé.

A.C.: la revista del GATEPAC [Magazine of GATEPAC], 1931-1937 (Madrid: Museo Nacional Reina Sofía, 2008).

A.C., 1 (1930-31).

A.C., $11(1933)$.

A.C., 13 (1934).

Arquitectura [Architecture] 141 (1970): special issue Secundino Zuazo.

Carlos María de Castro, Memoria descriptiva del Ante-Proyecto de Ensanche de Madrid (con estudio preliminar de Antonio Bonet Correa) [Descriptive Report of the Draft Expansion of the City of Madrid (with Preliminary Study of Antonio Bonet Correa)] (Madrid: COAM, 1978).

Carolina B. García and Josep M. Rovira, Casa Bloc (Barcelona: Mudito \& Co, 2011).

La Casa de las Flores [The House of Flowers] (Madrid: COAM, 2000).

Juan José Lahuerta, Le Corbusier e la Spagna [Le Corbusier and the Spagna] (Milano: Electa, 2006).

Jean-François Lejeune \& Michelangelo Sabatino (eds.), Modern Architecture and the Mediterrean: Vernacular Dialogues and Contested Identities (London: Routledge, 2010).

Lilia Maure Rubio, Anteproyecto del trazado viario y urbanización de Madrid: ZuazoJansen, 1929-30 [Draft of Road Outline and Urbanization of Madrid: ZuazoJansen, 1929-1930] (Madrid: COAM, 1986).

Fernando García Mercadal, La casa popular en España [The Popular House in Spain] (Madrid: Espasa-Calpe, 1930).

Lilia Maure Rubio, Secundino Zuazo, arquitecto [Secundino Zuazo, Architect] (Madrid: Fundación COAM, 1987).

Maure Rubio, "The New Ministries in Madrid: an Architectural Proposal by Secundino Zuazo," in Composición Arquitectónica - Art and Architecture 3 (June 1989): 103-136.

Josep Rovira et. al.., J.LL. Sert and Mediterranean Culture (Barcelona: Colegio de Arquitectos de Cataluña, 1995).

Rovira, "Ibiza y la mirada de la vanguardia," [Ibiza and the View of Forefront] in Urbanización en Punta Martinet, Ibiza, 1966-71 (Almería: Colegio de Arquitectos, 1996), 33-54.

Carlos Sambricio, "Hermann Jansen y el concurso de Madrid de 1929," [Hermann Jansen and the 1929 Competition of Madrid] in Arquitectura 303 (1995): 8-15.

Sambricio, "Zuazo in Caracas: The urbanism of exile in Venezuela 1937," in Planning Perspectives 28 (2013): 51-70.

Sambricio, "El bloque Las Flores, de Secundino Zuazo," [The House of Flowers of Secundino Zuazo] in RA, Revista de Arquitectura 15 (2013): 23-34

José Luis Sert, Can Our Cities Survive? (Cambridge: Harvard University Press, 1942).

\footnotetext{
${ }^{39}$ Quoted from La Casa de las Flores, Madrid: COAM, 2000, p. 3-4.
} 
Wolfgang Sonne, "Dwelling in the Metropolis: Sitte, Hegemann, and the International Dissemination of Reformed Urban Blocks, 1890-1940," in Jean-François Lejeune \& Charles Bohl (eds.), Sitte, Hegemann and the Metropolis: Modern Civic Art and International Exchanges (London: Routledge, 2009), 249-274.

Sonne, Urbanität und Dichte im Städtebau des 20. Jahrhunderts [Urbanity and Density in Urban Development of the $20^{\text {th }}$ Century] (Berlin: DOM Publishers, 2014).

Salvador Tarragó Cid, "El Pla Macià o La Nova Barcelona, 1931-38," [The Macia Plan or the New Barcelona, 1931-38] in Quaderns 90 (1972): 26.

Tarragó Cid,"El Plan Maciá, sintesis del trabajo del GATCPAC para Barcelona" [The Macia Plan, Summary of the Work of GATPAC to Barcelona], in $2 c-$ Construcción de la Ciudad 15-16 (1980): 68-85.

Secundino Zuazo, Madrid y sus anhelos Urbanisticos. Memorias, 1919-1940 [Madrid and its Urban Longings, Memoirs, 1919-1940] (Madrid: Comunidad de Madrid, 2003).

Zuazo, "La Reforma interior de Madrid," [Inner-city Reform of Madrid] in Arquitectura 7 (1934): 175-206. 